\title{
WHY DID RATING AGENCIES DO SUCH A BAD JOB RATING SUBPRIME SECURITIES?
}

\author{
Claire A. Hill ${ }^{*}$
}

\begin{abstract}
As of February 2008, Moody's had downgraded at least one tranche of $94.2 \%$ of the subprime RMBS issues it rated in 2006, including 100\% of the 2006 RMBS backed by second-lien loans and $76.9 \%$ of the issues rated in 2007. Overall, Moody's has downgraded $53.7 \%$ and $39.2 \%$ of all of its 2006 and 2007 subprime tranches, respectively.

As of March 2008, S\&P had downgraded $44.3 \%$ of the subprime tranches it rated between the first quarter of 2005 and the third quarter of 2007 . This included $87.2 \%$ of securities backed by second-lien mortgages.

As of December 2007, Fitch had downgraded approximately $34 \%$ of the subprime tranches it rated in 2006 and in the first quarter of 2007. In February 2008, Fitch placed all of the RMBS it rated in 2006 and the first quarter of 2007 backed by subprime first-lien mortgages on Ratings Watch Negative. ${ }^{1}$
\end{abstract}

\section{INTRODUCTION}

The three main rating agencies, Moody's, Standard \& Poor's, and Fitch, have been scorned and vilified for their bad performance in rating subprime securities. They gave AAA ratings to securities whose quality was far lower. Indeed, a significant proportion of subprime securities rated in years preceding the crash have been downgraded, often significantly; many of such securities have even defaulted. Why did rating agencies do such a bad job rating subprime securities? The conventional answer draws heavily on the fact that ratings are paid for by the issuers. There is a conflict of interest: Issuers could, and do, "buy" high ratings from willing sellers, the rating agencies.

The conventional answer cannot be wholly correct or even nearly so. Issuers also pay rating agencies to rate their corporate bond issues, yet very

* Professor and 2009-2010 Solly Robins Distinguished Research Fellow, University of Minnesota Law School. I wish to thank Ed DeSear, Scott Faga, Larry Isaacson, Paul Lawrence Rubin, and the participants at the Past, Present, and Future of the SEC conference at the University of Pittsburgh School of Law. I also wish to thank Matt Easterday, University of Minnesota J.D. 2009, for extremely capable research assistance.

1. Testimony Concerning Oversight of Nationally Recognized Statistical Rating Organizations: Hearing Before the S. Comm. on Banking, Housing, and Urban Affairs, 110th Cong. (2008) (statement of Christopher Cox, Chairman, Securities and Exchange Commission), available at http://sec.gov/news/ testimony/2008/ts042208cc.htm. 
few corporate bond issues are rated AAA. ${ }^{2}$ If the rating agencies were selling high ratings, why weren't high ratings sold for corporate bonds? Moreover, for some types of subprime securities, a particular rating agency's rating was considered necessary. Where a Standard \& Poor's rating was deemed necessary by the market, why would Standard \& Poor's risk its reputation by giving a rating higher (indeed, much higher) than it knew was warranted? Finally, and perhaps most importantly, giving AAA ratings to securities of much lower quality is something that can't be done for long. A rating agency that becomes known for selling its high ratings will soon find that nobody will be paying anything for its ratings, high or low.

In my view, that issuers pay for ratings may have been necessary for the rating agencies to have done as bad a job as they did rating subprime securities, but it was not sufficient. Many other factors contributed, including, importantly, that rating agencies "drank the Kool-Aid." They convinced themselves that the transaction structures could do what they were touted as being able to do: with only a thin cushion of support, produce a great quantity of high-quality securities. Rating agencies could take comfort, too, or so they thought, in the past - the successful, albeit short, recent history of subprime securitizations, and the longer history of successful mortgage securitizations. "Issuer pays" did not so much make the rating agencies give higher ratings than they thought were warranted as it gave the agencies a "can do" mindset regarding the task at hand - to achieve the rating the issuers desired, working with them to modify (tweak?) the deal structures as needed. That the issuers were paying motivated the agencies to drink the Kool-Aid; having drunk the Kool-Aid, the agencies gave the ratings they did. My account casts doubt on the efficacy of many of the solutions presently being proposed and suggests some features that more efficacious solutions should have.

This essay proceeds as follows. Section II provides some background, explaining the importance of rating agencies to the market for subprime securities. Section III briefly recounts how badly the rating agencies did in

2. See Jeff Sommer, INVESTING: DIARY; And Then There Were 9: A Shrinking Credit Club, N.Y. TIMES, July 29, 2001, at 37, available at $\mathrm{http}: / / \mathrm{www}$.nytimes.com/2001/07/29/business/investing-diary-andthen-there-were-9-a-shrinking-credit-club.html. The article notes that: “[o]nly 6.2 percent of debt in the $\$ 2.6$ trillion investment-grade corporate bond market carries the top rating, down from 10.2 percent in 1990 and 25 percent in 1979, [Moody's] said." See also Claire A. Hill, Regulating the Rating Agencies, 82 WASH. U. L.Q. 43, 65 n.104 (2004) [hereinafter Hill, Rating Agencies] (citing Marshall Blume et al., The Declining Credit Quality of U.S. Corporate Debt: Myth or Reality?, 53 J. FIN. 1389 (1998)), providing evidence that ratings have gotten more conservative over time, notwithstanding that rating agencies were being paid by the issuers. The Blume paper was published in 1998, but as of 2004, when the Regulating the Rating Agencies paper was published, my research found nothing to contradict it. 
rating subprime securities. Section IV sets forth the conventional wisdom as to why the rating agencies did so badly. Section $\mathrm{V}$ provides my argument as to why the conventional wisdom cannot be correct. Section VI sets forth my view as to what is correct, and provides arguments therefor. Section VII discusses how investors and other market participants have reacted to the rating agencies' bad performance. Section VIII appraises the solutions that have been proposed. Section IX concludes the essay.

\section{BACKGROUND}

The subprime securities whose collapse in value helped trigger the crisis were a type of debt security, or bond. Bonds, like any other assets, can be of greater or lesser quality. The best quality bonds (rated AAA) provide close to absolute assurance of timely payment; lower quality bonds, by contrast, are not nearly so certain to be repaid in full or on time. The higher the quality of a bond, the higher the price (or the lower the interest rate) it will command. The United States can borrow money a great deal more cheaply than can, for instance, Greece. ${ }^{3}$ Investors can, of course, make their own determinations of the quality of a bond; they can also look to the assessments of others, such as rating agencies. ${ }^{4}$

The history of rating agencies basically begins in the early 1900s, with the predecessors of the agencies that dominate the market for ratings even today, Moody's Investor Services and Standard \& Poor's. ${ }^{5}$ There have never been many rating agencies; indeed, Lawrence White notes that: "a striking fact about the structure of the [rating agency] industry is the persistent fewness of incumbents." The major agencies started out with a "subscriber pays" model,

3. Greece was recently downgraded by the rating agencies. As of this writing, the United States' rating-called the "sovereign debt rating"-is AAA, whereas Greece's sovereign debt rating is A- (Moody's and Standard \& Poor's) and BBB+ (Fitch). As to the United States' rating, see Pan Pylas, Sovereign Debt Fears Stalk World Markets, Assoc. Press, Dec. 9, 2009, available at http://www.google.com/ hostednews/ap/article/ALeqM5h3kgMAkbLwyfxBdjzw8Pc4KZ7DhQD9CFRV480. As to Fitch's downgrade of Greece, see Sovereign-debt Worries: Rate and See, THEECONOMIST, Dec. 10, 2009, available at http://www.economist.com/businessfinance/displaystory.cfm?story_id=15080551.

4. For many years, rating agency ratings have been very important to investors. Corporate bonds are very difficult to sell without ratings; structured finance securities, such as subprime securities, are impossible to sell without ratings. Two agencies, Moody's and Standard \& Poor's, used to have the great bulk of the business; more recently, in the area of structured finance, Fitch has also made some inroads. See Hill, Rating Agencies, supra note 2, at 46-48, 64.

5. Id. at $46-47$.

6. Lawrence White, The Credit Rating Industry: An Industrial Organization Analysis, in RATINGS, RAting AgEnCIES, AND THE GLOBAL FinANCIAL SYSTEM 41 (Richard M. Levich et al. eds., 2002), quoted 
in which they made their money from investors who used the ratings to make their investment decisions. The agencies switched to an "issuer pays" model when photocopying and other technology made it impossible for them to stop subscribers from sharing information with non-subscribers. ${ }^{7}$

For much of their history, rating agencies mostly rated financial instruments (bonds) that were relatively simple promises to pay. The source of repayment was often a large corporation with diverse business activities ${ }^{8}$ and, overall, many attributes - assets as well as liabilities. Such bonds are rarely rated AAA. While a company may wish to have the highest rating possible for its bonds, it has other objectives as well. One article noted: "[w]hile a triple-A rating brings lower borrowing costs and a certain prestige, many companies now prefer to take on debt to increase their return on equity. Utility companies once routinely received top ratings, [a Moody's economist] said, but none does so today." Moreover, a company's business plan might contemplate that it would take on some risks that could expose it to litigation or significant business reverses; this fact would be taken into account by a rating agency, and might result in a lower rating. ${ }^{10}$

More recently, however, rating agencies have gotten significantly involved in rating securities designed to be rated AAA; the securities at issue are sometimes called structured finance or securitization securities. Indeed, the securities were developed precisely to have high ratings. Rather than constituting general obligations of a corporation with diverse business activities, these securities are payable only from discrete and dedicated

in Hill, Rating Agencies, supra note 2, at 60.

7. See Frank Partnoy, How and Why Credit Rating Agencies are Not Like Other Gatekeepers, in FinANCIAL GATEKEEPERS: CAN THEY PROTECT INVESTORS? 62 (Yasuyuki Fuchita \& Robert E. Litan eds., 2006), available at http://papers.ssrn.com/sol3/papers.cfm?abstract_id=900257 (“[B]efore the 1970s, the agencies' business model was radically different from what it is today. Before the 1970s, when the Securities and Exchange Commission created the NRSRO designation and various regulations began to depend on NRSRO ratings, credit rating agencies made money by charging subscription fees to investors, not ratings fees to issuers. In contrast, today roughly 90 percent of credit rating agencies' revenues are from issuer fees."). See also Hill, Rating Agencies, supra note 2, at 50.

8. That being said, the first bonds to be rated were primarily railroad bonds. See Partnoy, supra note 7 , at 62 .

9. Sommer, supra note 2.

10. Indeed, very few companies are rated AAA. See Pfizer Gets Downgraded, Just Four Triple AAAs Remain, http://indexbeating.com/2009/10/22/4-aaas/ (Oct. 22, 2009, 7:48 EST). See Sommer, supra note 2. Sommer notes that

only nine companies in the United States now receive the top, triple-A rating, down from 22 a decade ago and 58 in the late 1970s. And only four of the top-rated companies of 1979-Merck, Bristol-Myers (now Bristol-Myers Squibb), General Electric, Exxon and Mobil (now Exxon Mobil)—still make the grade today, said Kamalesh Rao, a Moody's economist. 
repayment sources. The discrete repayment sources are usually receivables (that is, rights to receive payments, such as mortgage payments, credit card payments, and payments on other loans). The receivables are pooled and held by a separate entity created for the purpose. The entity sells securities; investors buying the securities get an interest in the receivables, and not in the receivables' originator. Thus, the securities represent promises to pay made by an entity created to make the promises, and with no other existence or role beyond its role with respect to the securities - the entity has no competing objectives. ${ }^{11}$

How are the high ratings achieved? The key is that not all securities the pool issues get high ratings. The pool will consist of many receivables of varying levels of quality. It will issue securities in "tranches"- that is, different repayment priorities. The more senior securities, those to be paid first, get AAA ratings. Other securities issued in a transaction get paid from funds remaining after the more senior securities are paid, and get lower ratings; the last tranche, often unrated, gets whatever remains. Critically, even if none of the receivables in the pool are of high quality, the pool can nevertheless issue some AAA securities. If the aggregate receivables in the pool have a face amount of 100 and are not completely positively correlated, surely some amount less than 100 will be paid with a high degree of confidence. ${ }^{12}$ The question becomes: how big an amount? Sophisticated modeling is supposed to provide a good answer to this question; until subprime mortgages were securitized, one could make a plausible case that it generally did so.

The structured finance transactions that paved the way for subprime securities began in earnest in the 1970s. While the rating agencies' task was a challenging one, the pool of assets (receivables) at issue in the early transactions consisted of real estate mortgages made to prime borrowers, an asset whose performance over time was quite well understood. As time went on, different types of assets have been securitized; some asset classes have also become quite well understood. ${ }^{13}$ Where that is the case, the transaction structuring becomes straightforward - the transactions are referred to as "cookie cutter."

But financial engineers are always thinking creatively, devising ways to securitize new assets. Mortgage-backed securities (backed by prime

11. See Hill, Rating Agencies, supra note 2, at 49.

12. I discuss this issue in Claire A. Hill, Who Were the Villains in the Subprime Crisis and Why it Matters, 4 ENTREPRENEURIAL BUS. L.J. (forthcoming 2010).

13. See generally Claire A. Hill, Securitization: A Low-Cost Sweetener for Lemons, 74 WASH. U. L.Q. 1061 (1996) [hereinafter Hill, Securitization]. 
mortgages) were old hat — why not try securitizing subprime mortgages? The engineers crafted elaborate algorithms to assist them in structuring the transactions, even though they did not have much past performance data to use. After all, lenders had been less than eager to make loans to subprime borrowers - the performance of such loans was not well known, and it was of course apt to be quite bad. But with someone to sell the loans to, lenders discovered a new enthusiasm for making them. Transaction volume soon reached startling heights, culminating in subprime issuances in the hundreds of billions of dollars. What's more, the financial engineers went much further, crafting exotic structures using not just mortgages and other "real" assets but also bets on the performance of certain assets - so called "synthetic instruments." The names for such instruments include $\mathrm{CDO}^{3}$ (CDO is an acronym for "collateralized debt obligations"; the superscript "cubed" means that the instruments were crafted from interests in interests in other instruments), and CDS (credit default swaps). There is general agreement that even by the standards of financial engineering, these structures are highly complex and, ultimately, not well understood.

And, for reasons well explored elsewhere, ${ }^{14}$ all the ratings business for subprime mortgage securities went to Moody's and Standard \& Poor's and one other rating agency, Fitch Investor Services, an agency created out of an amalgam of smaller agencies that specially positioned itself as an expert in structured transactions. Investors often wanted two ratings (and sometimes even three). For some types of structured finance instruments, investors required the ratings of one particular agency — often, Standard \& Poor's; the other agency could be either of the other two. In other cases, there could be a bit more competition, since any two agencies' ratings would do. ${ }^{15}$

\section{How BAD A Job the RATING Agencies Did}

The quotes at the beginning of this article tell the story. Here are a few more recent statistics:

Standard \& Poor's has downgraded about $\$ 1.37$ billion (42\%) out of about $\$ 3.28$ trillion in original issuance [of U.S. housing market-related securities], and an additional $\$ 1.49$ trillion (45\%) is still on CreditWatch negative for these vintages

14. See Hill, Rating Agencies, supra note 2, at 60, 64 .

15. This statement is based on interviews I have conducted with several leading structured finance practitioners. 
[2005-07] and sectors. About \$615 billion (19\%), however, was previously downgraded. ${ }^{16}$

So far, out of about $\$ 476$ billion in original issuance for these vintages and subsectors [U.S. Collateralized Debt Obligations of Asset Backed Securities and SIV lites], [S\&P has] downgraded about $\$ 418$ billion (88\%), and an additional $\$ 189$ billion (40\%) is still on CreditWatch negative. However, about $\$ 184$ billion was previously downgraded. ${ }^{17}$

Downgrades (and indeed, even defaults) by themselves do not necessarily indicate bad performance. Something no one could have expected might occur, causing an instrument to decline precipitously in value. Fancifully, what if aliens attack and everyone leaves their homes and goes to camp out in the desert (and of course stops paying their mortgages)? Or, more realistically, what if a few huge natural disasters occur at once, or a huge company is revealed to be a giant Ponzi scheme, there is panic, and as a result . . . . Furthermore, a significant part of what the rating agencies missed was missed by many other people, including some of the most sophisticated money managers: that housing prices might not only not continue to rise, but could instead decline throughout the whole country at the same time.

In this case, though, while it seems fair to say that some of what has happened could not have been predicted, there was clearly more readily available knowledge than was incorporated in rating agency models. Certainly, there is evidence that rating agencies were cutting corners. According to one article,

\footnotetext{
The agencies were inundated with a huge volume of new structured finance deals that they were being asked to rate. At Moody's, the flipside to the huge revenue growth was a high-pressure work environment. One analyst recalls rating a $\$ 1$ billion structured deal in 90 minutes. "People at the rating agencies used to say things like, 'I can't believe we got comfortable with that deal,", says Raynes [an individual employed by Moody's in the 1990s]. ${ }^{18}$
}

Corner-cutting may have been prompted by more than just huge deal volume. It may have been one mechanism rating agencies used to blind themselves to the possibility that their ratings may have been unwarrantedly high.

16. STANDARD \& POOR'S RATINGSDIRECT, Transition Study: Structured Finance Rating Transition and Default Update as of April 17, 2009, Apr. 24, 2009.

17. Id.

18. Sam Jones, When Junk Was Gold, FIN. TIMES (London), Oct. 17, 2008, at 16, available at http://us.ft.com/ftgateway/superpage.ft?news_id=fto101720081543437032. 
In 2001, Mr. Raiter [of Moody's Investor Services] was asked to rate an early collateralized debt obligation [CDO] called "Pinstripe." He asked for the "collateral tapes" so he could assess the creditworthiness of the home loans backing the CDO. This is the response he got from Richard Gugliada, the managing director: "Any request for loan level tapes is TOTALLY UNREASONABLE!!! Most investors don't have it and can't provide it. Nevertheless we MUST produce a credit estimate. ... It is your responsibility to provide those credit estimates and your responsibility to devise some method for doing so." Mr. Raiter was stunned. He was being directed to rate Pinstripe without access to essential credit data. He emailed back: "This is the most amazing e-mail I have ever received in my business career." 19

There were other signs that rating agencies were too eager to give high ratings. The following example (admittedly not involving subprime mortgage securities) is illustrative.

One instrument, the Constant Proportion Debt Obligation, was developed. The product had been designed by a crack team of credit experts at the Dutch bank ABN AMRO and was called the "Holy Grail of structured finance" by analysts at Bear Stearns. It had been built with a view to achieving triple-A ratings, but also promised to pay investors a substantial return-more than 10 times what comparable triple-A instruments were offering. CPDOs were not mortgage-backed, but rather collections of bets on the creditworthiness of hundreds of European and US corporations.

Moody's rated the first of the CPDOs in August 2006, after an unusually long analysis period. The rating it came up with was triple A-the closest thing you can get to risk-free. S\&P also gave it a triple-A rating. About two weeks after those first ratings came out, Fitch, which was not hired to rate any CPDOs, said it couldn't understand how they had been achieved: its own models had put CPDO bonds barely above junk grade. Fitch's doubts — echoed by a few other researchers - did not steal ABN AMRO's thunder. It was the new bestseller, and received this plaudit from Citi's research team: "Jokingly, we have started calling the product a Hydra. Almost every time we tried to kill it by subjecting it to severe stress, it seemed somehow to be able to recover par by maturity." 20

But Moody's turned out to have made a mistake.

A single small error in the computer coding that Moody's used to run its CPDO performance simulation had thrown the results way off. When the error was corrected, the likelihood of CPDO default increased significantly. CPDOs, it turned out, weren't triple-A products at all. Preliminary results suggested the error could have increased the rating by as many as four notches.

A meeting of the rating committee was hastily arranged, involving some of the most senior managing directors in the company's European structured finance

19. Credit Rating Agencies and the Financial Crisis: Hearing Before the H. Comm. on Oversight and Government Reform, 110th Cong. (2008) (statement of Rep. Henry A. Waxman, Member, H. Comm. on Oversight and Government Reform), available at http:/oversight.house.gov/images/stories/Hearings/ Committee_on_Oversight/Credit_Agencies_Hearing_HAW_Statement_10.22.08.pdf.

20. Jones, supra note 18. 
division. . . . The committee, however, did not disclose the error to investors or clients. The bug was corrected and the same model was then used to rate new CPDOs. But the new CPDOs still achieved triple-A ratings. The reason was that the committee made other changes to its code. A senior analyst proposed three alterations to the basic rating methodology. Two of them were adopted. The third was ditched because, as one document stated, "it did not help the rating."21

Moody's had been too eager to find a way for the instruments to be AAA; confronted with the discovery that their model that supported the AAA rating was flawed, rather than adjusting the ratings, they "fixed" the model so the instruments could continue to "be" AAA.

\section{ThE CONVENTIONAL WISDOM}

The conventional story is one of conflict of interest. Moody's, Standard $\&$ Poor's, and Fitch are paid by the issuers whose securities they rate. The issuers want the highest possible ratings so they can sell the securities for the highest possible amount. That this is a popular story is evidenced by the results of a search on the ALLNEWS database on Westlaw for "rating agenc!" /s conflict/s interest: the search yielded 1231 hits. In one article, a representative of Transparency International, an international agency that deals with corruption, was quoted as follows:

"The ratings agencies, in particular, had a conflict of interest and turned a blind eye towards high levels of risk. They were paid and trusted to give honest advice on financial products and we now have sufficient evidence to see that many did not. This is a form of corruption."

Mr. Poortman [global programmes director at Transparency International] accepted that some ratings errors had been the result of oversight or misunderstanding, but insisted others were deliberate. "I know of at least one instance where incorrect ratings were given for financial gain [by ratings analysts]."22

A search on Google for "rating agency conflict of interest" yielded 274,000 hits. One article notes that:

A survey of fund managers and institutional investors released Monday found that many believe significant conflicts of interest exist between ratings agencies and the entities they deal with.

Of the 1,956 investment professionals surveyed by the CFA Institute, $11 \%$ said they

had seen a credit rating agency change a bond grade in response to pressure from an

21. Id.

22. Michael Herman, Corruption Helped Cause Financial Crisis, THE TimES, (UK), Sept. 23, 2009, at 50 . 
issuer, underwriter or investor. Of the 211 respondents who said they had witnessed an agency change its rating in response to pressure, $51 \%$ said the pressure took the form of a threat "to take future ratings business to other" rating agencies.

The CFA survey went further to reveal that many respondents felt the most harmful conflict of interest results from the payment structure under which rating agencies such as Moody's Investors Service and Standard \& Poor's are paid by the same issuers whose securities they grade. ${ }^{23}$

In a recent opinion allowing claims against the rating agencies for common law fraud to proceed, the judge stated that: "Contrary to past practices where they were paid by investors, the Rating Agencies were compensated by the Cheyne SIV [the issuer of the securities] and Morgan Stanley at a fee substantially larger than that normally received and a fee that was directly connected to the success of the Cheyne SIV. This structure created a conflict of interest that compromised the objectivity of the ratings." 24

Joseph Stiglitz, Nobel Prize winning economist, also points to conflicts of interest:

The incentive structure of the rating agencies also proved perverse. Agencies such as Moody's and Standard \& Poor's are paid by the very people they are supposed to grade. As a result, they've had every reason to give companies high ratings, in a financial version of what college professors know as grade inflation. ${ }^{25}$

The SEC's report on credit rating agencies also cited the conflict of interest as a contributor to the subprime crisis, noting in its Summary Report of Issues Identified in the Commission Staff's Examinations of Select Credit Rating Agencies by the Staff of the Securities and Exchange Commission July 8, 2008 that "issues were identified in the management of conflicts of interest and improvements can be made." ${ }^{26}$ The report discusses quite a few other factors, though, some of which could have been caused by conflicts of interest, but others of which probably simply reflect less-than-thorough business practices. ${ }^{27}$ Thus, the press release announcing the report noted:

23. Neil Roland, Investors Cite Rating Agencies' Conflict of Interest, FIN. WEEK, July 8, 2008, available at http://www.financialweek.com/apps/pbcs.dll/article?AID=/20080708/REG/689125144/1/FWDailyAlert01.

24. Abu Dhabi Commercial Bank v. Morgan Stanley \& Co. Inc., 651 F. Supp. 2d 155, Fed. Sec. L. Rep. P 95,342 (S.D.N.Y. Sept. 2, 2009) (No. 08 CIV. 7508 (SAS)) at 176.

25. Joseph Stiglitz, The Economic Crisis, Capitalist Fools, VANITY FAIR, Jan. 2009, at 48.

26. OfFice of Compliance Inspections and Examinations, U.S. Securities and Exchange COMMISSION, SUMMARY REPORT OF ISSUES IDENTIFIED IN THE COMMISSION STAFF'S EXAMINATIONS OF Select CREDit RATINGS AgEnCies 2 (2008), available at http://www.sec.gov/news/studies/2008/ craexamination070808.pdf [hereinafter OFFICE OF COMPLIANCE INSPECTIONS AND EXAMINATIONS].

27. These practices should not be surprising, since the agencies have enjoyed a government-protected 
"We've uncovered serious shortcomings at these firms, including a lack of disclosure to investors and the public, a lack of policies and procedures to manage the rating process, and insufficient attention to conflicts of interest," said SEC Chairman Christopher Cox. "When the firms didn't have enough staff to do the job right, they often cut corners." 28

\section{CRITIQUING THE CONVENTIONAL WiSDOM}

The conventional wisdom about why rating agencies did such a bad job rating subprime securities mostly involves conflicts of interest. Issuers paid for high ratings, and got them. Incompetence sometimes plays a role in the accounts; sometimes the agencies are simply accused of haste and sloppiness, and sometimes, there is a broader indictment of how they operate and who they hire, especially at the lower levels. ${ }^{29}$

But the conventional wisdom can't be completely right. First, the "issuer pays" model has been dominant for quite some time. ${ }^{30}$ Nobody suggests regular corporate bond ratings are being bought and sold. Indeed, there is evidence that those ratings have gotten more conservative over time. ${ }^{31}$

Moreover, a critical part of the conflict-of-interest story is of course that the rating agencies competed for business, fearing a loss of market share. But this concern may be overstated. Many different types of transactions are rated. For particular types of transactions, the agencies are specialized, such that markets effectively require a rating from a particular rating agency. In such cases - and there were a fair number of them - an agency has no incentive to provide a higher rating than it believes is warranted.

Indeed, more broadly, the view that conflicts of interest caused the toohigh ratings in some straightforward way - an issuer told a rating agency that if the agency did not give the desired rating, the issuer would go to another

oligopoly until quite recently. See generally Hill, Rating Agencies, supra note 2, at 53-54.

28. Press Release, U.S. Securities and Exchange Commission, SEC Examinations Find Shortcomings in Credit Agencies' Practices and Disclosure to Investors (July 8, 2008), available at http://www.sec.gov/news/press/2008/2008-135.htm.

29. A search on Google for "rating agency incompetence" yields 2,010 hits; the same search performed without the quotation marks yields approximately 180,000 hits. One appears on the blog Naked Capitalism describing the Moody's fiasco discussed in the text herein. The post begins as follows: "Just when the world at large has become inured to the stories of the role of rating agency incompetence and complicity in our credit mess comes a bit of news that catches the attention of even the jaded." Posting of Yves Smith to Naked Capitalism, http://www.nakedcapitalism.com/2008/05/defective-moodys-programissues.html (May 21, 2008, 2:37 EST).

30. See Hill, Rating Agencies, supra note 2, at 50.

31. Id. at 65 . 
agency, and the agency succumbed to the pressure-embeds a strong and rather startling assumption. Consider that rating an instrument much higher than its quality warrants almost certainly can't work in the moderate term. A rating agency is consulted for its ratings only because those ratings are deemed by investors to be accurate. Issuers are paying for ratings, but if investors think high ratings can be bought, the ratings will be worthless, and rating agencies will lose all their business. Thus, the strong conflict argument turns on enormous agency costs - many people at the agency being willing to go for the quick buck, knowing that in the moderate term the agency would suffer enormously, as would, presumably, their long-term job prospects at the agency (and perhaps elsewhere). The short-term payoffs were high - the agencies were indeed making huge quantities of money. ${ }^{32}$ But they weren't making enough money to look as foolish as they do now, ${ }^{33}$ or be as vulnerable to litigation and more onerous regulation as they are now. Indeed, if rating agencies had had some suspicion of just how wrong their ratings were, they would have had to expect lawsuits. While they have always done well when they were sued previously, they could scarcely have been cavalier about the possibility. Indeed, the lawsuits being brought now are advancing, and may lead to the assessment of huge damages. ${ }^{34}$

32. "Although many of their ratings turned out to be catastrophically misleading, the large rating agencies enjoyed their most profitable years ever during the past decade." Kathleen L. Casey, Comm'r, U.S. Sec. and Exch. Comm'n, In Search of Transparency, Accountability, and Competition: The Regulation of Credit Rating Agencies (Feb. 6, 2009), available at http://www.sec.gov/news/speech/2009/ spch020609klc.htm.

33. Interestingly, notwithstanding their regular vilification as discussed in the text, they seem to have retained and to some extent recaptured considerable credibility with investors. See infra notes $45-47$ and accompanying text.

34. See, e.g., Leslie Wayne, CalPERS Sues Over Ratings of Securities, N.Y. TIMES, July 15, 2009, at B1, available at $\mathrm{http} / / / \mathrm{www}$. nytimes.com/2009/07/15/business/15calpers.html (describing CalPERS lawsuit). The lawsuits (including CalPERS) include the following: Ohio Police \& Fire Pension Fund v. Standard \& Poor's Fin. Serv., No. 09-CV-01054 (S.D. Ohio filed Nov. 20, 2009); Connecticut v. McGraw Hill Co., Inc., No. 3:08-CV-01316-AWT, 664 F. Supp. 2d 196 (D. Conn. Sept. 30, 2009) (remanding to Connecticut state court); In re Moody's Corp. Sec. Litig., 599 F. Supp. 2 d 493 (S.D.N.Y. 2009), reh'g denied, 612 F. Supp. 2d. 397 (S.D.N.Y. 2009); New Jersey Carpenters Vacation Fund v. HarborView Mortgage Loan Trust 2006-4, 581 F. Supp. 2d 581 (S.D.N.Y. 2008); Louisiana Mun. Police Employees Retirement Sys. v. McDaniel, No. 1:08-CV-09323-SWK (S.D.N.Y. filed Oct. 30, 2008) (consolidated with In re Moody's Corp. Sec. Litig., 599 F. Supp. 2 d 493 (S.D.N.Y. 2009) at 07-CV-8375 (SWK), Dkt. No. 7); Ind. Laborers' Pension Fund v. Fimalac S.A., 1:08-CV-05994-SAS (S.D.N.Y. voluntarily dismissed Oct. 3, 2008); New Jersey Carpenters Health Fund v. The Royal Bank of Scotland Group, PLC, No. 1:08-CV05310-DAB (S.D.N.Y. filed June 10, 2008); CalPERS v. Moody's Corp., No. CGC-09-490241 (Cal. Super. Ct. filed July 9, 2009) removed to federal court and remanded to state court, CalPERS v. Moody's Corp., No. 3:09-CV-03628, (N.D. Cal. filed Nov. 10, 2009), and Abu Dhabi Commercial Bank v. Morgan Stanley \& Co., Inc. et al., 1:08-cv-07508 (S.D. N. Y.). An unfavorable holding for the agencies was in a recent 


\section{An Alternative ACCOUNT}

If the conventional account is not accurate, what is the alternative? There was, indeed, some jockeying among the rating agencies for market share - certainly, the quotes in the preceding section indicate that there was some concern over competitive position. But the strong-form view, predicated as it is on the notion that rating agencies really were being paid for high ratings - that is, that they knew or deliberately avoided knowing that the securities didn't warrant such ratings, but gave them to preserve or increase their market share-hypothesizes something very unlikely. That is, it hypothesizes that the agencies were acting to their benefit in the very short term in a manner that would have been disastrous in the moderate term. Short term, the agencies would have preserved or increased market share; moderate term, with downgrade and perhaps default of highly rated instruments, there would be considerable loss of market share, perhaps leading to the agencies' failure. $^{35}$

Thus, it seems more likely that such jockeying for market share as was occurring was being done against a backdrop of something broader: a general belief that we had entered a brave new world in which risk had, to overstate the case a bit, been conquered. Indeed, for at least the past decade, many on Wall Street managed to persuade themselves that "quants" or "rocket scientists" could develop new instruments that would offer reward far greater

decision in the Abu Dhabi case, Abu Dhabi Commercial Bank v. Morgan Stanley \& Co. Inc., 651 F. Supp. 2d 155, Fed. Sec. L. Rep. P 95,342 (S.D.N.Y. Sept. 2, 2009) (No. 08 CIV. 7508 (SAS)). The judge rejected an argument rating agencies had long made successfully, that their ratings are protected by the First Amendment, and that they are non-actionable opinions, and allowed some of the claims against them to proceed. The agencies have won some victories, though. Moody's Investor Service, Inc. and McGraw-Hill, the owner of Standard and Poor's recently succeeded in getting a complaint against them dismissed. Judge Kaplan held that their activities in connection with rating a MBS transaction for Lehman affiliates did not give rise to liability as underwriters or control persons for purposes of the Federal securities laws. In re Lehman Bros. Securities and Erisa Litigation, __ F. Supp. 2d__, 2010 WL 337997 (S.D.N.Y. Feb. 1, 2010) (No. 09 MD 2017 (LAK)). Judge Kaplan also ruled for Fitch, Moody's and McGraw-Hill in In re IndyMac Mortgage-Backed Securities Litigation, Case 1:09-cv-04583-LAK, Feb. 5, 2010, stating that he was dismissing the case against them for the same reasons as were stated in his ruling in Lehman Bros.

35. I should acknowledge here an ultra-cynical perspective: The agencies really did know how false their ratings were, made them anyway, and counted on stickiness of the sort I describe in Section VII to limit any costs to their behavior. I can't prove this isn't so, but it seems unlikely, especially given my interviews with structured finance lawyers describing rating agency employees' honest-seeming beliefs in what they were doing and their energetic attempts to improve the quality of the assets backing subprime securities, demanding and getting changes to the asset pools. 
than the commensurate risk. ${ }^{36}$ The quotes in the section above on the CPDO ("The product had been designed by a crack team of credit experts at the Dutch bank ABN AMRO and was called the 'Holy Grail of structured finance' by analysts at Bear Stearns. It had been built with a view to achieving triple-A ratings . ..."37 ) illustrate the point. Add to this the can-do mindset that did reflect "issuer pays" and a picture emerges in which the agencies believed complex high-quality instruments that warranted high ratings could be created, and worked with their "clients" the issuers to do so.

Many market participants - including ABN AMRO and Bear Stearns as described above- "drank the Kool-Aid" that reflected belief in the brave new world of manageable (and managed!) risk. Many were indeed persuaded by the very high-tech instruments at issue in structured finance. Those criticizing - and, indeed, vilifying - the rating agencies say that the rating agencies were somehow particularly chargeable with identifying failings in the securities - in getting the ratings right. Rating agencies are, after all, "gatekeepers," certifying credit quality. The argument has considerable merit as a normative matter - rating agencies should get it right. But if I am correct, their failure to do so does not reflect some kind of deep culpability. Rating agencies are indeed in the business of assessing credit quality, but many brilliant and sophisticated market participants with considerable amounts of money at stake and considerable access to information about the securities and about markets generally made the same mistake the rating agencies did. These instruments were not bought by widows and orphans who might more reasonably have unquestioningly relied on rating agency ratings. Moreover, many of the market participants involved had previously expressed some skepticism about the savvy of rating agencies. And they had done so even before the Enron debacle, in which a company whose bonds the rating agencies still rated investment grade four days before the company declared bankruptcy. ${ }^{38}$

Not everyone drank the Kool-Aid, of course. Money manager John Paulson made billions betting against the performance of subprime securities. ${ }^{39}$

36. Steve Lohr, In Modeling Risk, the Human Factor Was Left Out, N.Y. TIMES, Nov. 5, 2008, available at $\mathrm{http}: / / \mathrm{www}$.nytimes.com/2008/11/05/business/05risk.html.

37. See supra note 18 .

38. See Hill, Rating Agencies, supra note 2, at 43.

39. "John Paulson's bets on the implosion of the U.S. housing market will go into the 'annals of Wall Street lore,' said Nat Worden on TheStreet.com. Last year two funds managed by his New York-based firm, Paulson \& Co., were up $\$ 15$ bn or $600 \%$, netting the unassuming Paulson an estimated $\$ 3$ bn $-\$ 4$ bn in fees." The Wall Street Investor Who Shorted Subprime — and Made \$15bn, MONEYWEEK, Jan. 28, 2008, available at http://www.moneyweek.com/news-and-charts/the-wall-street-investor-who-shorted-subprime--and-made- 
In addition, various personnel at many of the institutions involved sensed trouble: a general lessening of credit standards, haste and complexity that precluded care and thorough review, and so on. This included rating agency personnel. ${ }^{40}$ In this regard, an SEC report on the rating agencies' conduct in the crisis sets forth many cautionary notes sounded by ratings employees, including the following:

\begin{abstract}
Email No. 1: Analytical Staff to Analytical Staff(Apr. 5, 2007, 3:56 PM). In another email, an analytical manager in the same rating agency's CDO group wrote to a senior analytical manager that the rating agencies continue to create an "even bigger monster - the CDO market. Let's hope we are all wealthy and retired by the time this house of cards falters." Email No. 2: Analytical Manager to Senior Analytical Manager (Dec. 15, 2006, 8:31 PM). ${ }^{41}$
\end{abstract}

Rating agencies predisposed to working with their "clients" the issuers to achieve high ratings could find comfort in the prestige and personal stakes of the market participants involved: the investment banks that structured the deals and retained huge exposure themselves, the hedge funds providing insurance on the performance of the instruments, etc. They also had several other sources of comfort. First, they frequently asked for changes in deal structures to raise the quality. This was their tried-and-true methodology for securities they had successfully rated. ${ }^{42}$ Indeed, their past success at rating complex securities - admittedly not as complex as those at issue in the crisis - was of significant comfort as well. Finally, insofar as they had fallen flat before with Enron, with the so-called "Asian flu" (collapse of Asian economies), and in a few other instances, they could distinguish those instances from the brave new world they had entered. Enron involved fraud; the Asian flu involved complex

\footnotetext{
15bn.aspx.

40. And some rating agency employees, including senior ones, may have known far more. See, e.g., Abu Dhabi Commercial Bank v. Morgan Stanley \& Co. Inc., 651 F. Supp. 2d 155, Fed. Sec. L. Rep. P 95,342 (S.D.N.Y. Sept. 2, 2009) (No. 08 CIV. 7508 (SAS)) (“. . . plaintiffs have sufficiently pled that the Rating Agencies did not genuinely or reasonably believe that the ratings they assigned to the Rated Notes were accurate and had a basis in fact."). Id. at 176.

41. See Office of Compliance Inspections And Examinations, supra note 26, at $12 \mathrm{nn} .7-8$. Interestingly, a search on Google for "Enron house of cards" yields 63,800 hits.

42. In this regard, note that rating agencies claim they were not involved in "structuring" the securities. If they were so involved, their vulnerability in a variety of contexts becomes much greater. Whether or not as a technical or legal matter rating agencies were involved in structuring subprime securities, they certainly worked closely with the issuers to identify how the deals should be structured to achieve the desired ratings.
} 
international macroeconomic events, etc. Thus far, modeling, even complex modeling, had worked well for them. ${ }^{43}$

A final factor, consistent in this case with some conventional critiques, is quasi-bureaucratic insulation from competition leading to less-than-cuttingedge methods and, in some cases, personnel. Until recently, the government effectively limited access to the rating agency business to Moody's and Standard \& Poor's, and to a lesser degree Fitch. ${ }^{44}$ It seems possible, if not likely, that this dulled an edge that competitive markets might have sharpened in the caliber of the agencies' performance. ${ }^{45}$

\section{How Have InVEStors Reacted to Rating AgenCIES’ BAD PERFORMANCE?}

Astonishingly, where their investment practices are concerned, investors apparently have barely reacted. The agencies have been vilified, yes, but, notwithstanding their spectacularly bad performance with subprime securities and their spectacularly bad performance not so long beforehand with Enron and some other debacles as well- the Asian Flu and Executive Life come to mind-investors are still trusting them. Indeed, a recent article is called In Rating Agencies, Investors Still Trust. ${ }^{46}$

The words sound almost quaint in this post-subprime age: "Credit. Man's Confidence in Man." But there they are, inscribed on a gilded frieze on the 20th floor of the Moody's Corporation - the same Moody's that, along with its peers, stamped gilt-edged credit ratings on many mortgage securities that are now nearly worthless.

43. Claire A. Hill, Why Did Anyone Listen to the Rating Agencies After Enron?, 4 J. Bus. \& TECH. L., 283, 284 (2009). See Fitch Ratings, Fitch Ratings 1991-2005 U.S. Structured Finance TRANSITION STUDY (2006), available at http://www.fitchratings.com/dtp/pdf3-06/5fit0707.pdf; see also Moody's Investors Service Global CREdit Research, Special Comment: Default \& Loss Rates OF Structured FinANCE SeCURities: 1993-2005 (2006), available at http://www.moodys.com/ cust $/$ content/content.ashx? source $=$ StaticContent/Free+pages $/$ Credit + Policy + Research $/$ documents $/$ current /2005600000426138.pdf.

44. See Hill, Rating Agencies, supra note 2, at 44; see also Frank Partnoy, The Paradox of Credit Ratings, in RATINGS, RATING AgENCIES, AND THE Global FinanCIAL SySTEM 65-84 (Richard M. Levich et al. eds., 2002), at 74; see also Rating Agencies and the Use of Credit Ratings Under the Federal Securities Laws, Exchange Act Release Nos. 8236, 47972, 68 Fed. Reg. 35258 (June 12, 2003) [hereinafter SEC Concept Release]; U.S. SECURITIES AND EXCHANGE COMMISSION, REPORT ON THE ROLE AND FUNCTION OF Credit Rating Agencies in the Operation OF the SeCurities Markets 6-9 (2003) [hereinafter SEC REPORT], available at http://www.sec.gov/news/studies/credratingreport0103.pdf.

45. Frank Partnoy, The Siskel and Ebert of Financial Markets: Two Thumbs Down for the Credit Rating Agencies, 77 WASH. U. L.Q. 619, 632, 703 (1999); Hill, Rating Agencies, supra note 2, at 81.

46. David Gillen, In Rating Agencies, Investors Still Trust, N.Y. TIMES, June 4, 2009, at B1, available at http://www.nytimes.com/2009/06/05/business/economy/05place.html. 
Few have any confidence in those investments now. So it might come as a surprise that many investors still seem to have a lot of confidence in Moody's. Despite talk of a big shake-up for the tainted credit-ratings establishment, things seem to be looking up, not down, for the likes of Moody's. The granddaddy of the industry, Moody's has become something of a stock market darling in this, its 100th year. Its share price is up nearly 44 percent this year. At nearly $\$ 29$ on Thursday, the stock was hovering near its highest level since the dark days of last September." ${ }^{, 7}$

Even in the area of structured finance, the very area in which the rating agencies did such a disastrous job, investors are still turning to the agencies.

Even after the disastrous performance of recent years, the Big Three remain deeply entrenched. In September, four companies-Bank of America, Nissan, Discovery and American Express - issued structured finance bonds, worth more than $\$ 6$ billion, and paid Moody's to rate them. ${ }^{48}$

Meantime, to the consternation of detractors, the [rating agencies] are now earning fees from a new source: re-Remics, an acronym for resecuritization of real estate mortgage investment conduits. These are transactions that take downgraded mortgage securities and separate the riskiest assets from the strongest, making the strongest easier to sell. ${ }^{49}$

All of this suggests that the practice of using ratings from Moody's, Standard \& Poor's, and Fitch is quite sticky: even considerable evidence that they can be spectacularly wrong, and be so because of slipshod methods and a less than critical mindset — or worse - doesn't make investors demand that issuers go elsewhere.

Why is the practice of going to the same rating agencies so sticky? I have argued elsewhere that:

The individuals making the day-to-day investment decisions have guidelines, practices, and "form" documents, all providing for purchase of debt instruments rated by Standard \& Poor's and Moody's, from which they don't have reason to deviate. The firm that created the guidelines, practices, and forms also has no strong reason to change them. Moreover, the incentive structures of the individuals within the firm tend to discourage efforts at form-changing. Such incentive structures may reflect the firm's desire to keep transaction costs low. Moreover, insofar as the guidelines, practices, and forms establish process-based standards that use a wellaccepted measure of safety for investment decisions, the firm may also be seeking to streamline lawsuits by disappointed clients on whose behalf it made losing investments. Indeed, courts have remarked with favor on an investor's due diligence process that includes use of ratings by Moody's and Standard \& Poor's. Finally,

\footnotetext{
47. Id.

48. Id.

49. David Segal, Debt Raters Avoid Overhaul After Crisis, N.Y. TIMES, Dec. 8, 2009, at A1, available at $\mathrm{http} / / / \mathrm{www} . n y t i m e s . c o m / 2009 / 12 / 08 /$ business/08ratings.html?dbk.
} 
many money management firms are judged by how well they perform relative to particular indices; the indices are composed of debt chosen by reference to Moody's and Standard \& Poor's ratings. As much as they might like to exceed the indices, money management firms (and the individual money managers) cannot reliably do so. They are far better off trying to do no worse. The best strategy to do no worse is to mimic the relevant index. And even parties who are simply seeking to hold funds temporarily rather than attempting to earn a return, such as parties holding funds in escrow, are subject to, and help to perpetuate, the norm: guidelines, practices, or documentation (or, probably, all three) governing funds held in escrow arrangements may provide that the funds are to be invested in securities that are highly rated by Moody's and Standard \& Poor's. ${ }^{50}$

Perhaps if the rating agencies do badly in one or more of the cases presently brought against them, investors may be less inclined to stick with them. But given investor trust post-Enron and post-subprime securities debacle, it would probably have to be a major loss indeed.

\section{APPRAISING PROPOSED SOLUTIONS}

Regulation of rating agencies has become a hot topic, with proposals coming from both the SEC and the legislature; the Obama administration has also submitted proposed legislation to Congress. Some new regulations have been enacted. In what follows, I briefly summarize and appraise the types of approaches that have been suggested. ${ }^{51}$

- Some proposals emphasize increased disclosure to the SEC and, in some cases, to the public.

- Some proposals emphasize increased oversight by the SEC.

50. Hill, Rating Agencies, supra note 2, at 61-62.

51. The proposed statutes are: H.R. 1181, 111th Cong.; Credit Rating Agency Transparency and Disclosure Act, H.R. 1445, 111 th Cong. §_ (2009); Credit Rating Agency Responsibility Act of 2009, S. 927, 111 th Cong. §_ (2009); Rating Accountability and Transparency Enhancement Act of 2009, S. 1073, 111th Cong. §_ (2009); Rating Accountability and Transparency Enhancement Act of 2009, H.R. 3214, 111th Cong. §_ (2009); Consumer Protection and Regulatory Enhancement Act, H.R. 3310, 111 th Cong. $\S$ _ (2009). (Relevant portions are Title VI (sections 601-603); Wall Street Reform and Consumer Protection Act of 2009, H.R. 4173, 111 th Cong. §_ (as passed by the House, Dec. 11, 2009) (relevant portions are Title V, Subtitle B, (sections 6002-6013), which is the: Accounting and Transparency in Ratings Act); Accountability and Transparency in Rating Agencies Act, H.R. 3890, 111 th Cong. §_ (2009). There are also proposed SEC regulations: Re-proposed Rules for Nationally Recognized Statistical Rating Organizations, 74 Fed. Reg. 6485 (proposed Feb. 9, 2009) (to be codified at 17 C.F.R. pts. 240 and 243); References to Ratings of Nationally Recognized Statistical Rating Organizations, 74 Fed. Reg. 52374 (proposed Oct. 9, 2009) (to be codified at 17 C.F.R. pts. 229, 230, 239, 240, 242, 249, 270, and 275); Proposed Rules for Nationally Recognized Statistical Rating Organizations, 74 Fed. Reg. 63866 (proposed Dec. 4, 2009) (to be codified at 17 C.F.R. pts. 240 and 249b). 
- Some proposals impose requirements on NRSROs regarding corporate governance, specifics about ratings practices, and other matters.

- Several proposals address conflicts of interest.

- Some proposals eliminate or limit the use of the "Nationally Recognized Statistical Rating Organization" designation in statutes and regulations. NRSRO is a designation granted by the SEC to a rating agency. Securities rated highly by NRSROs are much more desirable to investors than those without such ratings - they allow investors to, among other things, hold much lower amounts of capital. The NRSRO designation has been called a "regulatory license." 52 The SEC used to have quite a bit of discretion in granting NRSRO designations; as a result of Enron, the rules were changed to require the SEC to grant the designation more expansively, and it has done so. ${ }^{53}$ That being said, to become an NRSRO, an agency's ratings need to be generally accepted and, for agencies without the "regulatory license," there is a certain catch-22: An agency cannot become generally accepted without the NRSRO designation, and it cannot get the designation without being generally accepted. ${ }^{54}$

- Some proposals would impose fines, penalties, or censure on NRSROs.

I am skeptical of all these proposals. In the previous Section, I argued that there is considerable "stickiness" in the choice of rating agency. Straightforward market mechanisms clearly haven't helped discipline the agencies, as investors seem to rely on them even after they've performed exceedingly badly. More disclosure and oversight don't seem likely to help either; why should the SEC be able to detect what self-interested money managers - those buying the securities in hopes of a big return - were not? The SEC may have legal power, but market participants had power too- to be skeptical of ratings and demand better evidence of the quality of the securities they were buying. And now, market participants have extensive and quite unfavorable disclosure of the agencies' methodologies and results - disclosure that does not seem to be motivating any kind of different behavior. What about requiring the rating agencies to have better rating procedures, better internal controls, and better corporate governance? Presumably, rating agencies are moving in this direction in any event. And, given what has been revealed, it scarcely seems likely that bad procedures, controls or governance would have overridden the mindset I have described. Surely, given any plausible construction of what the agencies did, the agencies' ratings were problematic given their existing procedures, controls and governance-yet they assigned them anyway. The will to achieve a higher rating would seem to trump the

52. See Partnoy, supra note 45.

53. See, e.g., Press Release, Seven Credit Rating Agencies Register with SEC as Nationally Recognized Statistical Rating Organizations (Sept. 24, 2007), available at http://www.sec.gov/news/ press/2007/2007-199.htm.

54. See Hill, Rating Agencies, supra note 2, at 55. 
types of additional roadblocks that requirements of this sort would put in its way.

What about better management of conflicts of interest? Here, again, skepticism would seem to be in order. I have argued that the can-do mindset is what really wrought havoc; ultimately, if issuers are clients, even if there are all sorts of formal separations, the mindset may very well influence how the agencies do their jobs. Moreover, another important component of the mix - an underlying belief in the powers of financial engineering's "rocket scientists" to magically minimize risk-is notoriously resistant to disconfirmation.

What about making ratings less important by removing the "regulatory license," the favorable treatment accorded to purchases and holdings of securities highly rated by an NRSRO? Given post-Enron pressure and changes in the law that made more agencies NRSROs, ${ }^{55}$ if regulatory licenses were what was keeping investors from demanding that issuers use other agencies, we might have expected to see some appreciable diminution of the major agencies' market share. We have seen nothing of the kind: Moody's, Standard $\&$ Poor's, and Fitch have retained their market shares even where investors could choose other NRSROs. Thus, it would seem that even if no rating agency had a regulatory license, stickiness might keep investors with the major agencies even regardless of disastrous performance. This is not to say that in the moderate term, a world where rating agency ratings don't give various regulatory advantages might not be a better one. Indeed, such a world might also be one in which there was vigorous competition among rating agencies; with respect to the "catch-22" referred to above, competition could be purely on the basis of quality, with new entrants not hobbled by needing extensive past history. The problem is in the transition - it seems hard, if not impossible, to "get there from here," and considerable damage might be done in the interim. In this regard, I argued elsewhere:

The easiest proposal to defend on theoretical grounds is probably the elimination of the NRSRO designation and replacement with a more market-based solution. But there are considerable perils of eliminating NRSRO designation too quickly . . , if the process is not carefully managed, the effect may be the opposite of what was intended: to more firmly entrench Moody's and Standard \& Poor's. ${ }^{56}$

55. See supra text accompanying note 53 .

56. See Hill, Rating Agencies, supra note 2, at 93. 
And entrenchment might be the good news scenario. Alternatively, the trajectory from an oligopolistic market to a more competitive one could lead to something even worse. If regulatory reforms succeeded "in appreciably increasing the number of rating agencies[,] companies then might be able to play the rating agencies off one another, as they were able to do with their accounting firms. ${ }^{\text {"57 }}$ While straightforward conflicts were not the whole story of the rating agencies' bad job in rating subprime securities, jockeying for market position was definitely a factor, albeit significantly constrained because of stickiness in the continuing use of Moody's, S\&P, and Fitch. If the stickiness were to erode appreciably such that the rating agency industry became truly competitive, agencies might engage in an all-out race to the bottom, competing on laxity by offering higher ratings than were warranted. Of course, they could not directly admit to doing so-rather, they would have to couch their laxity as greater sophistication, as some accounts suggest Fitch may have done to get appreciable market share in rating structured finance securities. While this strategy couldn't work in the moderate term, it might work in the short term. And it might not be the result of conscious design: An agency could convince itself that its high ratings were actually deserved, just as the agencies convinced themselves that the subprime securities ratings were deserved. Thus, unless something were done about the "issuer pays" model, about which I will have more to say below, a quite competitive rating agency industry might be truly bad news, at least in the short term.

Lawsuits do not seem too promising either: Surely, prospectively, the rating agencies will take care not to leave a record of telling people that looking at underlying documentation is "unreasonable." No one would seriously propose making rating agencies guarantors of the ratings they give, or make them strictly liable. Rating agencies could surely avoid any kind of fault-based liability by adopting and adhering to appropriate procedures. But these procedures would not have prevented agencies from relying on the flawed but commonly held assumptions that underlay their models, and were huge contributors to their flawed ratings - that housing prices would continue to rise.

What about penalizing NRSROs? Here, my skepticism is founded on the same arguments I made above with respect to oversight and lawsuits. When a rating agency knows particular behavior will subject it to discipline, it will ensure that it does not engage in that behavior. But proscribed behavior will necessarily be specified via process, and process can be adhered to 
mechanically. Specifying substantively the requirements for rating "well" is impossible.

One suggestion sometimes made is that rating agency performance would be improved if rating agencies had more of a direct financial stake in the correctness of their ratings. ${ }^{58}$ The obvious form for such a stake is the rated securities themselves, given to the agencies as part of their compensation for rating the securities. The suggestion is intriguing. My suspicion, however, is that it is ultimately unworkable. Attempts at getting the incentive alignment right may still leave open perverse incentives, incentives to misrate, given how many ways there are to make bets on the performance of debt securities. Moreover, the problem to be solved is supposedly that issuers were paying for ratings higher than were warranted. Compensating rating agencies with the debt they are rating is supposed to serve as a counterweight. How big a proportion of the rated securities would the agencies need in order to give them the appropriate incentives? Not too big, one hopes, given that the reason the securities are being issued are for them to be sold to third parties. Perhaps one could minimize the amount required with complex instruments the agencies could get that would mimic the performance of the relevant securities. But the fix would be hard to get right. Moreover, whatever the proportion given, couldn't the issuing firm just increase the price paid for the too-high rating to compensate for the agency's loss on the securities?

The difficulty in getting the agencies to give 'correct' ratings is compounded by the fact that the ratings themselves affect the security's quality. A security is rated when issued; while the security is outstanding, its rating is reviewed and upgraded or downgraded if appropriate. The act of upgrading or downgrading, itself, affects a security's value, insofar as it affects

58. A recent example is Yair Listokin \& Benjamin Taileson, If You Misrate Then You Lose; Improving Credit Rating Accuracy Through Incentive Compensation, forthcoming, YALE J. ON REG. 2010, available at $\mathrm{http}: / / \mathrm{ssrn}$.com/abstract=1535514. The authors acknowledge that an effective fix would be quite complex; a simple fix, wherein agencies would, upon rating an issue, get some of their compensation in the form of the securities they were rating, won't work. The authors offer suggestions for complex fixes that address the problems they identify with simple fixes. Because securities can be upgraded and downgraded, they should be given out over time, not just at the time of the initial issuance. And puts and calls may be required as well. The authors acknowledge that some of their fixes may be so complicated as to not be worth the increased incentive alignment. ("This Section ... develops a more complicated incentive compensation scheme whereby misrating incentives are further reduced through the use of put and call options. While it is likely that the complexity induced by this scheme would be more costly than its incentive-improving effects, the 'put and call' proposal is an example of how creative use of incentive compensation plans can further reduce the risk of misrating." Id. at 108-09.) I wonder whether, notwithstanding the conceptual promise of the approach, instantiations that provided sufficient incentive alignment wouldn't always be on some important metric too complex. 
who can buy it, who must sell it if they own it, and (rarely relevant for structured finance securities) whether additional financing may be available to the issuing entity. If a rating agency's own action can affect the value of the security it holds, the agency would have an incentive potentially contrary to the incentive the authors count on, to give the 'correct' rating.

Finally, I have argued that an important reason why rating agencies did such a bad job rating subprime securities is that they were able to fool themselves. Notwithstanding that they were being paid by the issuers, they did have significant incentives not to wildly misrate - as I have discussed previously, if people think high ratings are bought rather than earned, they won't pay anything for them. Misrating also carries reputational costs, as well as the potential for loss of market share and the prospect of lawsuits. Thus, while the potential financial cost might provide a counterweight to misrating, I wonder how much of an increased counterweight it would be over and above the incentives already existing.

\section{CONCLUSION}

Why did the rating agencies do such a bad job rating subprime securities? The story being told - of conflicts of interest - holds considerable appeal. The rating agencies are to be vilified! And we need to spend our energies addressing conflicts; we can put in place more procedures to guard against conflicts, and in any event, make them work harder and better, with more extensive oversight and vulnerability to litigation.

But like many simple stories, this one captures some truth but leaves out a great deal more. The reality is, as reality tends to be, far more nuanced. And the nuances matter as we are considering policy solutions. In the previous Section, I argued that I was skeptical of all the presently proposed solutions: greater oversight and disclosure, measures to deal with conflicts of interest, greater vulnerability to litigation, eliminating the NRSRO designation or imposing fines or censure on NRSROs or withdrawing their designations.

What seems to be needed is ratings that reflect true critical input. Perhaps issuers should be required to use two ratings, one of which has to be from an agency paid by subscriber/investors or some intermediary? No one seems to be seriously proposing this. Perhaps the government might create an agency that would serve as second rater? Greater government involvement has been suggested, but the idea hasn't gotten much traction. ${ }^{59}$ Of course, these ideas are 
scarcely easy to put into practice. How would the subscriber or intermediary-paid firms come to be available and willing to be second raters? Would there be enough such firms? If government were to be the second rater, how would it acquire the needed expertise? If government effectively had a monopoly on the 'second rater' position, would it do a good enough job? These are serious questions - and they will surely be quite difficult to satisfactorily address. In the short term, investors are still "fleeing to quality" - the crisis is too recent for many, and probably most, of them to be able to justify buying unproven securities in hopes of getting higher yield. But memories are notoriously short. It is not at all clear that rating agencies won't yet again grievously mis-rate. We may need to focus our attentions elsewhere.

Approaches I have proposed in other work include encouraging investors to rely less on the agencies, stronger regulation of how much leverage firms can have, enhanced motivations and perhaps responsibilities for other gatekeepers, and creation of mechanisms to collect and act on information about a bubble in the making. ${ }^{60}$ Perhaps in the moderate term true competition will come to the industry, or the problem will be solved in some other manner. But the present trajectory, coupled with the long history of attention to rating agency regulation after debacles that leads to nothing, suggests that considerable skepticism is in order. This is not to say that rating agency ratings have no value - indeed, in the normal course, the ratings do quite well. It is, rather, to say that rating agencies can get it spectacularly wrong, in ways that can do real damage, and we haven't yet figured out a way to prevent that from happening in the future.

60. See Claire A. Hill, Why Didn't Subprime Investors Demand (Much) More of a Lemons Premium? forthcoming, LAW \& CONTEMP. PROBS. 